\title{
A NEW GIS-BASED MAP OF VILLA ADRIANA, A MULTIMEDIA GUIDE FOR ANCIENT PATHS.
}

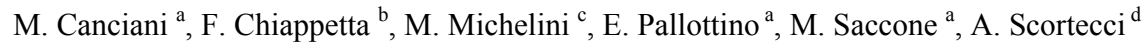 \\ ${ }^{a}$ Dipartimento di Architettura, Università degli Studi Roma Tre, 00153 Roma, Italy - (marco.canciani, elisabetta.pallottino, \\ mauro.saccone)@uniroma3.it \\ barch.fchiappetta@gmail.com \\ c manuelamichelini2010@gmail.com \\ dalicescortecci.2009@gmail.com
}

Commission V, WG V/2

KEY WORDS: Photogrammetry, Cartography, GIS, Digitisation, Georeferencing, Cultural Heritage, 3D reconstructions, Multimedia guide

\begin{abstract}
:
For the last fifteen years the Faculty of Architecture at the University of Roma Tre, has been working on the famous Villa Adriana in Tivoli, studying its ruins and its ancient paths, in order to better understand how the villa was originally laid out. In this paper, we will talk about one of these studies, which reconnect previous works and creates a new GIS based map of Villa Adriana.

The goal of this study is to create a cultural heritage evaluation. In order to achieve this aim, we have created a multimedia guide with text, drawings, 3D reconstructions and augmented reality. This work can be summarized in five steps; first of all, a new georeferenced plan was created. This drawing is based on an orthophoto and brings together all existing surveys (from historical drawings to recent surveys). In this new work we show the current status of the ruins and the original layout of Villa Adriana according to the most recent study. The second step was a 3D survey, with extensive use of photogrammetry to verify and upgrade drawings. The next and third step involved creating the Database, within which to store, edit, analyze, share, and display linked data relating to both ancient and contemporary buildings and pathways. This GIS is based on the new plan and gathers together different orders of information: original function, paving, the old paths of each original user (Hadrian, his wife Sabina, the retinue, guests and servants) as well as the ancient system of underground tunnels. It collects all the existing data relating to Villa Adriana relevant to solving the 'what/where' question. The fourth step was to create a complete 3D model of Villa Adriana. The 3D reconstruction started from the existing surveys, the documentation of recent excavation and the input of the hypothetical reconstruction of lost or buried buildings.

Finally we created a multimedia guide, based on a mobile app, which took information from the database to show, in real time, during the tour, where you are and what you can see around you. With this app it's possible to read information about the villa's original layout, or you can access information about the ancient users (their lives and paths). You can also see 3D reconstructions of the buildings around you.
\end{abstract}

\section{PREFACE - PHILOLOGY AND VALORIZATION. THE CONTRIBUTION OF EDUCATION AND UNIVERSITY RESEARCH.}

Thanks to the far-sighted and passionate teaching of Paolo Marconi, is now more then two decades that the Architecture Faculty of the University of Roma Tre, now a Department, has been dealing daily with a history of architecture aimed at the activity of restoration. It also promotes, through education and research, exegetical courses aimed at the philological understanding of pre-modern architectonic contexts both in series and exceptional and the constructive traditions of various Italian histories and geographies.

If the results have been immediately visible in the area of education it is because philological practice has provided diverse generations of students with knowledge of the linguistic detail of the tradition. Equally important were the effects on the culture of restoration of ancient and modern architecture and on the possible recovery of the beauty of historical centers. Philological restoration, for example, in Rome at the Borrominian complex of St. Carlino at the Four Fountains and of the portico of St. Giorgio in Velabro (La "Fabrica", 2007; La chiesa, 2002), have demonstrated that the public administration predisposed towards protection - like the Ministry for public assets, cultural activities and tourism - can turn to the contribution of the universities both in terms of single research projects and in more methodological areas. Analogous sharing and harmony are desirable for the future of historical centers compromised by the recent earthquakes and waiting for physical and social rebirth, like the City of L'Aquila not far from Rome (Com'era, dov'era, 2009).

Analogous philological studies can be turned to the comprehension of archeological contexts of consolidated ruins, thanks to the contribution of a history of ancient architecture made by architects and also thanks to the curiosity of those who, today, delve into their ancient function and recognize it as a priority also in terms of valorization.

In fact, valorization too, on equal terms with education and architectonic and urban restoration, can be informed and qualified by a philological reading. Suggesting pathways which augment understanding of ancient use can help to restore the real sense of archeological sites and avoid those valorization initiatives which are sometimes arbitrary or merely financial in nature. This is even easier in the contexts which over time have remained substantially immune to processes of stratification, like Villa Adriana, and in particular the case of study which we propose to follow.

The monumental entrance to the Grand Vestibule, which has only recently come to light and been studied by the authors of the excavations. The study that we present here is the last result 
in a line of operational and historical research which begins with the extraordinary publication by Eugenia Salza Prina Ricotti (Salza Prina Ricotti, 1982; Salza Prina Ricotti, 2001) an architect with a considerable knowledge of Hadrian architecture. The book by Federica Chiappetta on the ancient pathways of the Villa (Chiappetta, 2008) is a planned philological consequence of Ricotti's work. It is completed today with the new and essential contribution provide by modern instruments for valorization, (from 3D surveys to the construction of territorial GIS, multimedia platforms, Web GIS and now applications for mobile devices). These have been finalized by Marco Canciani and Mauro Saccone in the Department of Architecture at the University of Roma Tre in order to make proposals for valorization with immediate potential.

The two publications - the already mentioned book by Chiappetta and the research presented today by Manuela Michelini and Alice Scortecci - were born as a thesis from the auspicable integration of education and research. Therefore, this study takes advantage of multidisciplinary relationships and correlations and external collaboration, as it should, given that it is a work which intends to respond to the complex demands of the public administration. We bring it to the attention of the scientific community and we offer it to the use that the Superintendent for archeological heritage in the Lazio Region can and should make of it. We are grateful for the support and interest shown by the superintendent Elena Calandra and the director of the Archeological area of Villa Adriana, Benedetta Adembri and also for the contribution of Zaccaria Mari to the direct knowledge of the Grand Vestibule. If the situation allows, then it is their task to study the feasibility of programs of valorization which result almost directly from the ancient context as described below. It is not necessary that the underlying richness and complexity of this research need necessarily involve elevated implementation costs.

\section{THE ANCIENT WORKING OF VILLA ADRIANA.}

“[...] gli Edifizj di questa Villa superavano ogn'altro tanto per la loro magnificenza, che per l'ornamento, e per la lor vaga, e bizzarra figura: Dalle quali molto possono profittare i Professori di Architettura". This is the conclusion in the caption of the map of Villa Adriana designed by F. Piranesi at the end of the 1700s (Piranesi, 1781). The words still tell the story of the ruins of the Villa but today, more than in the past, we can admire the work of experimental design carried out by the great mind who knew how to join the beauty of architectonic composition with an extraordinary investigation of rational functionality.

At Villa Adriana you can see diverse types of architectonic work, destined to the various categories of its inhabitants. Each one conceived and designed to carry out some of the multiple functions required by the Villa. The buildings for habitation, from the most sumptuous destined to the imperial family to the dormitories for the lowest servants. The numerous buildings of court designed to house guests of various ranks (Figure 1); the luxurious and more modest thermal baths as well as the buildings for spectacles and services of every type.

The buildings are laid out along various disconnected axes which render the plan apparently casual but which respond however to the reason of composition and perspective which guides the alternation of buildings and spectacular architectures of water and green in order to provide life to brilliant visual invention, part of which can still be appreciated today (MacDonald - Pinto, 1997).

We are not dealing with, however, a design based merely on composition. On the contrary the Villa is the result of a united design where human needs are cared for with extreme precision.

This is proven by the water and sewage system and above all by the extensive network connecting the functional arteries of the complex capable of linking and supplying each and every part. (Salza Prina Ricotti, 1982; eadem, 2001; Chiappetta, 2008).
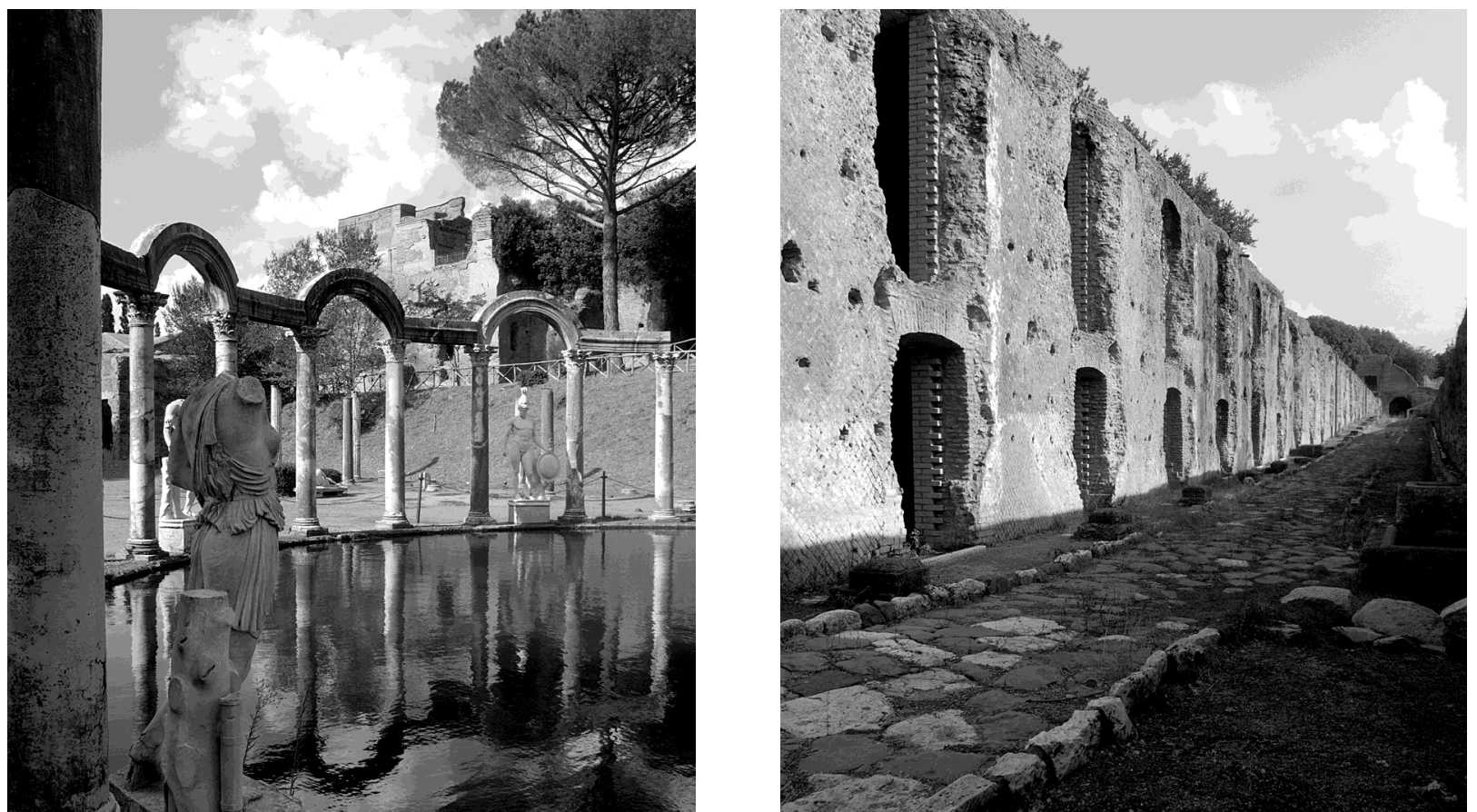

Figure 1: Detail of the Canopo canal (the so called tricline of water) [foto di G. Foti].

Figure 2: The carriageway $\mathrm{C}$ of the servants and the Cento Camerelle, habitation of the servants [foto di G. Foti]. 
Villa Adriana is, in fact, regulated by a system of roads and pathways, with alternating tracts in tunnels and others in the open but all facilitating the movement of the grand mass of the servants while, at the same time, permitting the imperial family to rapidly reach their residences and for their guests to find their courtly accommodation. This principal system was connected to the internal communication system which connected the various buildings or part of them. These were galleries to be travelled on foot, partly by servants with lateral routes which never crossed paths with those of the nobles for whom were reserved the monumental carriage and walkways.

Even the entrances giving access to the Villa were quite different. There were two principal ones. The first was found at the center of the long Pecile wall while the second and more important of the two was the Grande Vestibolo consisting of two entrances, one noble which reached the building by way of a monumental staircase with ornamental nymphs and the other service entrance placed below and connected directly to the servants' quarters (Figure 2). Other less luxurious but not less important functionally travelled along the via carrabile $\mathrm{B}$, which followed a trench towards the south arriving at the Grande Trapezio, an enormous hypogeal interchange leading to the imperial entrance and that of the servants and the Accademia which gave access to the actors and spectators headed for the Odeon.

Unfortunately the major part of these communication networks, like some buildings or parts of them are inaccessible to visitors who remain ignorant of the real nature of that intelligent organism, pulsing with daily life which was Villa Adriana, which today suffers a universal fame based more on its nature as a marvelous but indistinct archeological landscape than a real understanding of the architectonic and historical significance of the remains which make up that landscape.

\section{RELATED WORKS.}

In order to add value to the cultural heritage study and in particular the archeological areas, there are diverse methodological approaches which we have divided into three large groups. In each case, the principal objective is the study and conservation of the heritage site or monument and as such the most relevant aspects of this work are the 3D survey (Remondino, 2011), the advanced modelling (De Luca et al. 2011; Canciani, 2013) connection of the metadata as three dimensional objects (Drap, 2009; Agugiaro, 2011) and more generally, the management and interpretation of all data obtained from excavations for the works of restoration and conservation (Ardissone, 2013). This type of data requires multi-layer instruments capable of connecting diverse data in order to help with study and decision making processes. The instruments utilized up till now are mainly of two types - GIS and BIM with potentials and limitations which are different between them (Saygi, 2013).

In the second research group, the working focus has been on communicating the contents of the site to a public which might be more or less informed including middle school students, high school students or general visitors including tourists without special knowledge of the field. The instruments for adding value are largely multi-media platforms in which $3 \mathrm{D}$ modelling, rendering and animation occupy a predominant position (NoReal.it, 2011a). Often, with the objective of allowing people to get to know the heritage site, one aims at the possibility of visiting the site at a distance (Pietroni, 2012a) by using virtual tours (Kohel, 2013), virtual globes (Brovelli, 2013) or spherical photometry (De Amorim, 2013). In order to interest a younger public, and increase the didactic potential, interactive games and virtual realities are created (Pietroni, 2012b). Finally, for a public which is used to technology, in many museums and archeological areas 3D environments and augmented reality have recently been developed (NoReal.it, 2011b).

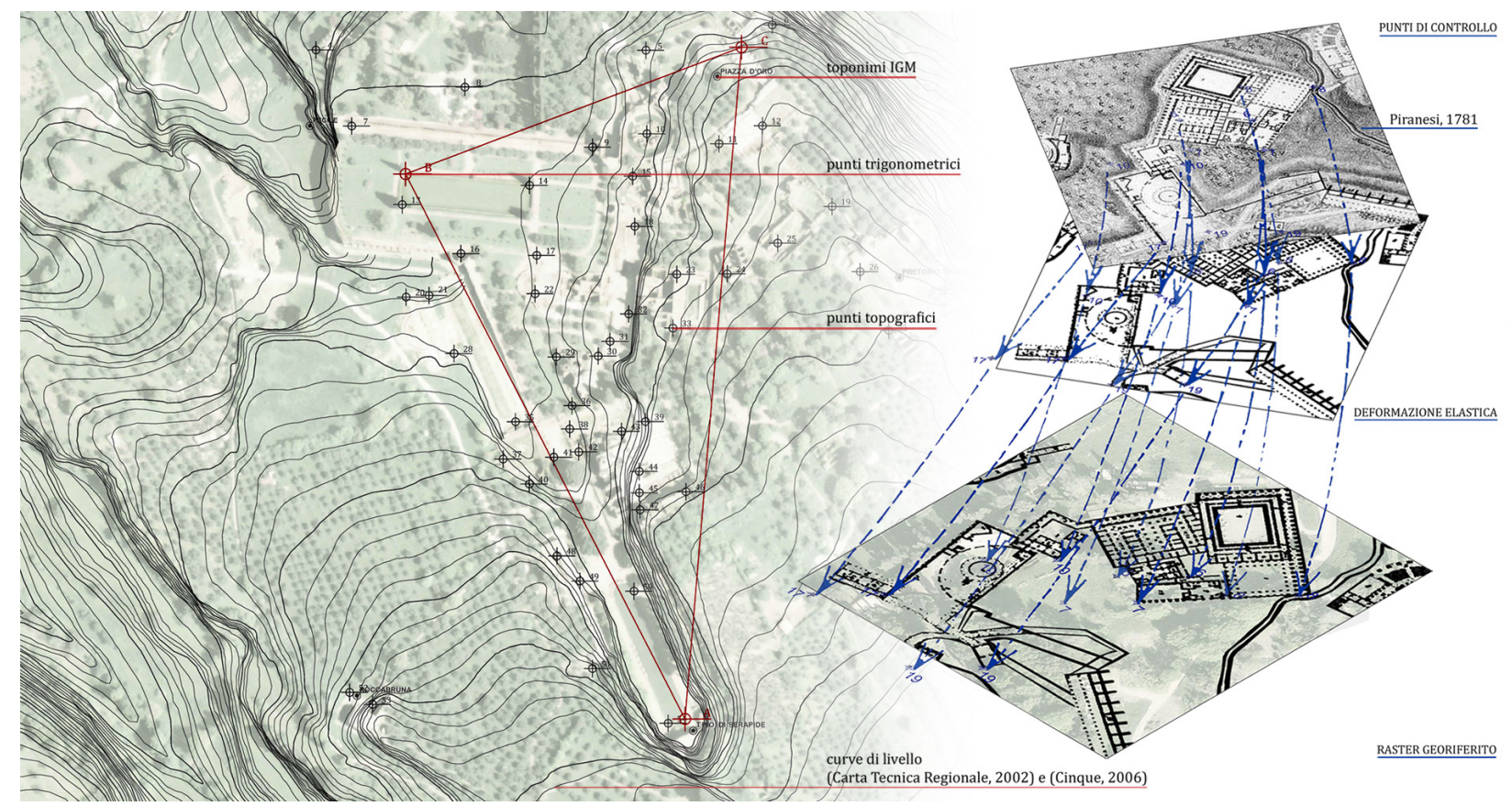

Figure 3. New investigation methods using GIS. 


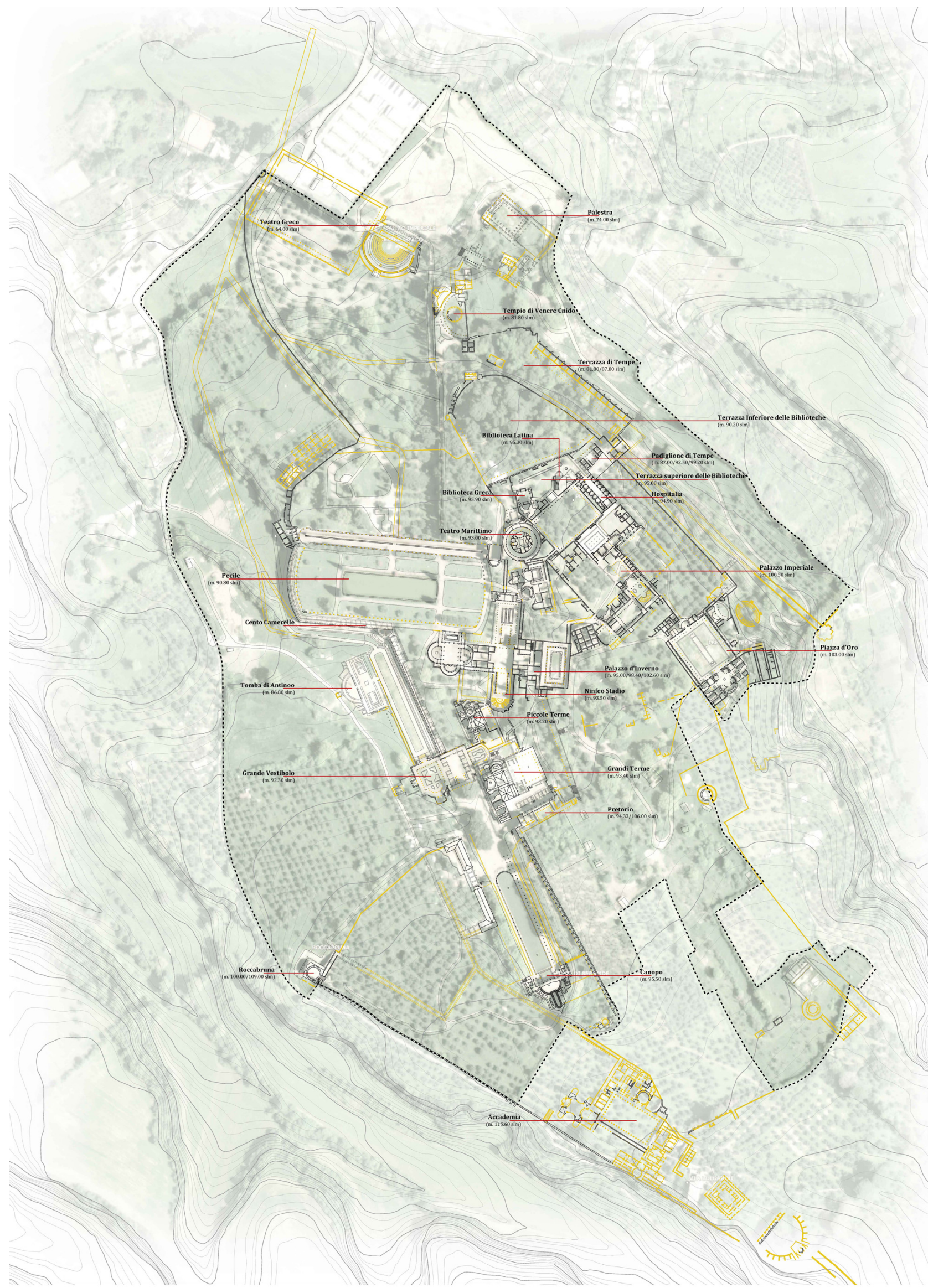

Figure 4.The new GIS based Map of villa Adriana. 
In the third and last study group, which is more closely tied to our work, the research which mainly exploits the Web-GIS as an operational instrument is included (Salonia, 2005). In these works, we present the maps and ancient sources with historical topography and archeological findings (Panella, 2008). This means we are dealing with studies which try to blend together both the scientific and educational aspects.

The principal aspect of these studies is a relevance to scientific data which becomes public through the use of the Web-GIS (Forte, 2007; Pescarin, 2009). Our contribution to this research group exploits the possibility of transferring information from the Web-GIS to a mobile tool (telephone or tablet) via a multimedia application which will be presented further on.

\section{NEW INVESTIGATION METHODS USING GIS.}

The use of a Geographic Information System is an obligatory choice when you want to manage all the data of a complex so large (about 56 hectares), and so structured (about 40 open spaces and buildings) such as Villa Adriana in order to make them accessible both to the scholar and the visitor. Much more is needed when there is a lack of digital maps that present the actual state of the villa, updated to the present day, in relation to existing buildings and archaeological and original arrangement. The work, carried out by the GIS, was designed precisely to overcome this gap, through the creation of a GIS-based reference map of Villa Adriana and analysis of complex issues through data processing.

Regarding the first point, the new geo-referenced plans of Villa Adriana are an ex-novo product which systematically orders a tradition of study and which takes advantage of historic maps and recent excavations, including areas that are not public domain. Initially, an archive of the topographical sources and most credible surveys was created starting from those of Piranesi, published from 1781 up to the modern day; this operation was carried out systematically utilizing AutoCAD Map3D software which allowed the managing of cartographic data within a reference system of geographical coordinates. The choice of the geodetic reference system (WGS84_Utm Italy33) is followed by the creation of a cartographic base built on the georeferenced orthophoto. On it have been chosen a number of points, related to important buildings and used to place all of the graphic sources. Each of these systems has been placed systematically with the others, through georeferencing operations, getting overlap and comparison, which are indispensable for connecting and interrelating different information. From the collation of these heterogeneous data, two new general plans of the villa were created. The first, divided into two sectors, illustrates the ancient complex by showing the walls in existence today, those which are documented but have disappeared, the system of pathways, the gardens and the ponds which originally ornamented the villa. The second relates the updated current state, with an indication of ancient and modern carriageways, accessible and not accessible spaces and the architectural elements which are documented but no longer visible (Figure 4).

Regarding the second point, the S.I.G. has allowed us to examine the entire complex, connecting specific data, associated with single buildings, the ancient and current road system and all the other elements which make up the Villa, in relation to their map position. This tool has allowed us to carry out various studies, summarized in thematic maps, which quantify specific aspects, such as the quality of the experience of the visit. This has been evaluated by measuring the following indicators: the conservation of the ancient roadway system, the accessibility of the buildings and the current usability of the ancient pathways. The analysis notes that the tourist is allowed to use only an area of 27 hectares compared to 56 hectares of government property. With regard to the places and locations of the emperor, for example, it should be noted that the percentage of accessibility is reduced to $16 \%$ and that the path of Hadrian is useable for $40 \%$ (Figure 6).
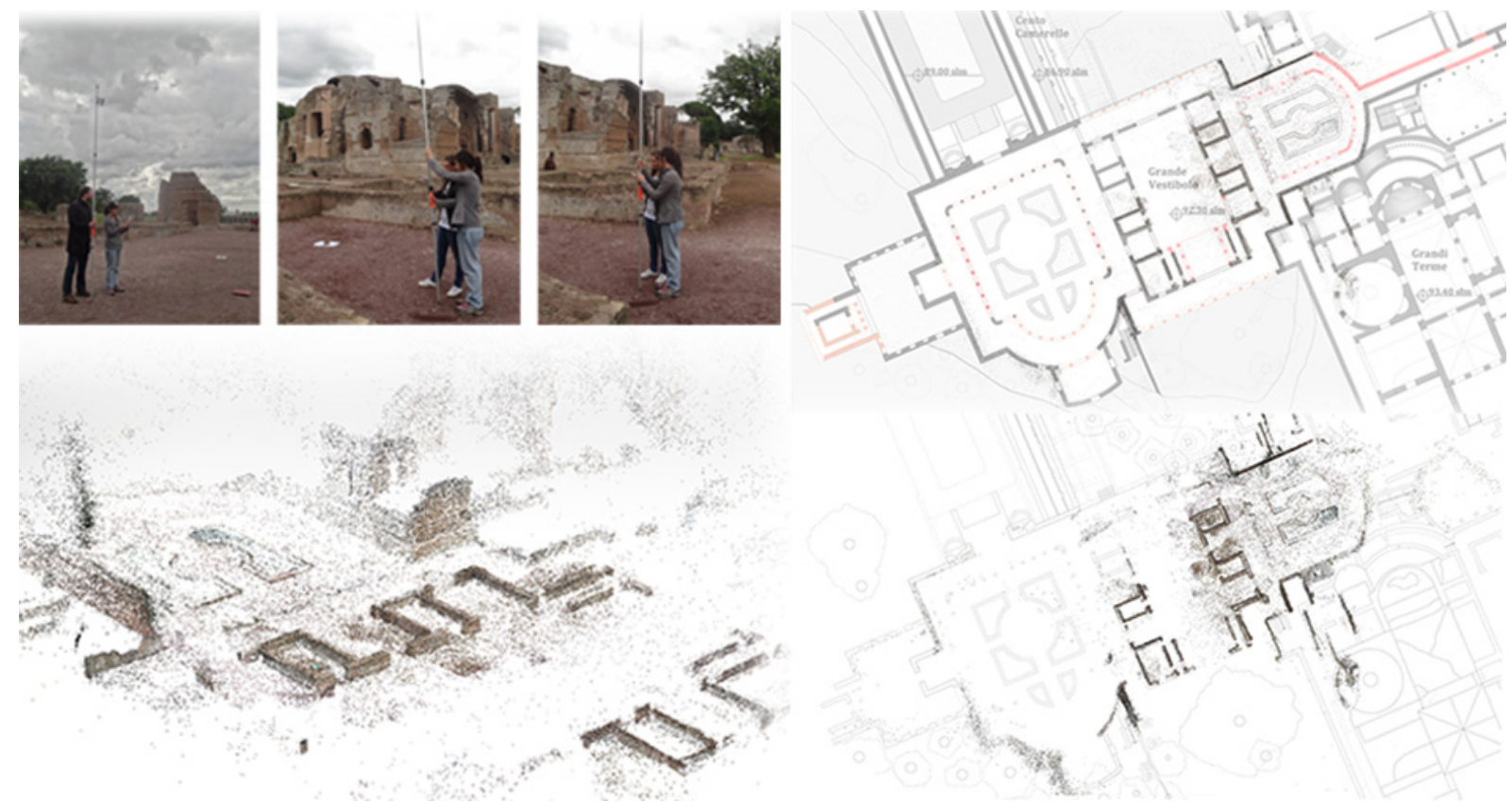

Figure 5. Photogrammetric survey. 


\section{THE GRAND VESTIBULE: THE MONUMENTAL ACCESS TO THE VILLA.}

The work of analysis is followed through with research at building scale. The choice of the Grand Vestibule is derived from the state of research, from its architectonic and functional characteristics and from its state of conservation. It was the monumental entrance and as such, an access point for various buildings. Today, it is on the most frequently used visitor's pathway, but its state of conservation and its partial accessibility make it a mere passageway. The system of pathways which leads to it, even if it has been restored, is not passable and as such is difficult to comprehend. Furthermore, the system of galleries which underlies it, created in ancient times for servant access, is hidden from the eyes of the visitor. In order to quantify this problem for the Grand Vestibule we adopted the methodology outlined previously with a deeper level of investigation.

The first phase involved editing the map (fig.) for which six graphic fonts were used, the surveys of: G.B. Piranesi, Reichardt, Reina-Barbieri, Ricotti, Sgalambro and G. Cinque. All of the plans were compared and georeferred using sixteen topographic points relating to the building.

Successively, a photogrammetric survey was carried out. The point cloud (Figure 5) was restituted with a set of 300 photographs using a camera mounted on a telescopic pole, controlled at a distance with a tablet. The software used for the post-processing includes Microsoft Photosynth (Photosynth.net) for point cloud and Meshlab (Meshlab.net) to create the mesh model and elaboration. The overlap of this model with the previously cited plan and the historical maps has allowed the verification and integration of the new map of the Grand Vestibule. Based on this verified map the GIS was created at building scale, and compared to the one of the entire Villa it has been enriched with information. It is made up of 515 polygonal topologies and five linear topologies for old pathways. The data gathered are relative to: the phases of construction, ancient usage, the pavements and original relevance, library sources, current accessibility and state of conservation.

One of the most relevant analyses involves the current usability of the Grand Vestibule (Figure 6). The results demonstrate that the original pathway is negated by the current one. In fact only $49 \%$ of the first level environment is accessible and the underground area (even though it is in an excellent state of conservation) is completely inaccessible.

\section{MULTIMEDIA GUIDE FOR THE VISIT TO VILLA ADRIANA.}

As in our premise, our project is a multimedia application for mobile devices which facilitates the understanding of the ancient layout of Villa Adriana based on the ancient pathways. The GIS was originally developed with AutoCAD Map3D software and subsequently we chose to move to the ArcGIS Online platform in order to share analyses, data and geographical content. This software foresees the creation of applications which permit access to the Maps in ArcGIS Online. With this App all the GIS data are navigable and interactive on your own portable device. In our specific case, the app captures all the data contained in the GIS and functions are based on the position of the user.

The app is an instrument both for visitors and for "specialists". It guides you through the archeological site, illustrates usable and non-accessible ancient pathways and makes clear the relationships between single monuments. The user is specifically identified via a GPS sensor and their position determines the selection of data to be consulted.

The app is organized into three menus: 'Villa Adriana', 'The inhabitants of the Villa', and 'The Visit'. The contents of the first two can also be consulted from outside the archeological site in that they function independently from the position of the user. The contents are always available and organized according to hierarchical levels which allow the user to discover the ancient layout of the Hadrian residence through

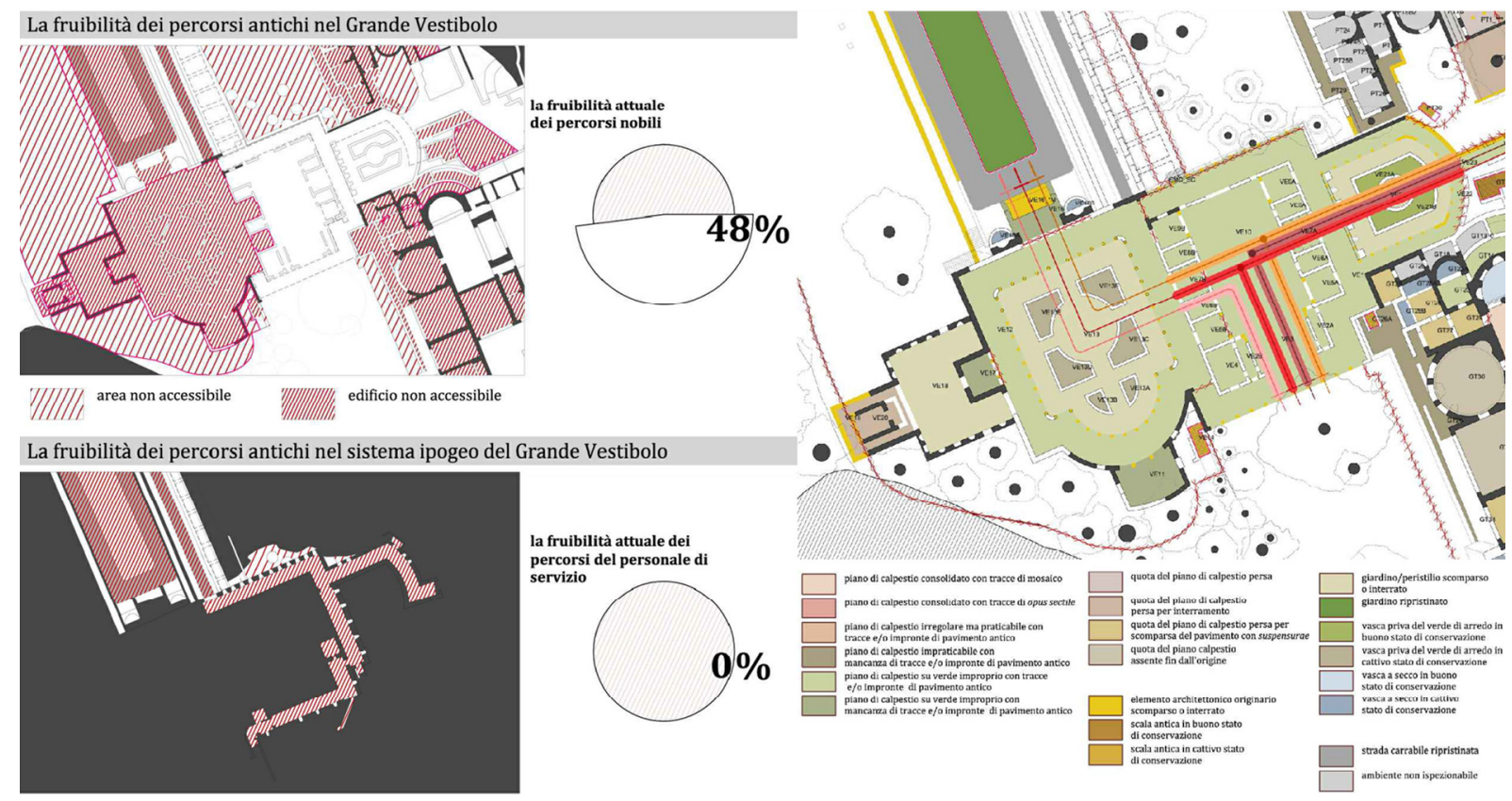

Figure 6. Usability of the Grand Vestibule. 
texts and graphic documentation (Figure 7). The contents of the third menu are an interactive map which allows the exploration of the Villa. The map, according to the position of the user shows different information superimposed on the current map. The user can see the architectonic elements lost or buried, the ancient road system, the original pathways and so on. The map also presents connections with data sheets designed for every single monument and road. These sheets offer a descriptive part and extra information about, for example, for the Grand Vestibule show the ancient functions, pathways, original pertinence, bibliographical sources, graphic sources and the phases of construction.

During the elaboration of the valorization project, the analysis of the current state, has lead us to not establish a single 'guided tour'. For this reason all the data (sheets, drawings, text.) are always related to what the visitor has around them.

\section{CONCLUSION.}

As illustrated previously, the experience of the current visit makes it difficult to understand the original function of the villa, the complex network of ancient pathways is mainly lost or inaccessible. Many buildings or part of them are closed to the public and the didactic systems are of scarce value or obsolete. The valorization of the archeological site as proposed will therefore be created through the development of the multimedia app. In addition to the use of the interactive map we have simulated an additional function for the mobile app which exploits augmented reality (Figure 8). The 'Augmented Reality' function can give the tourist the possibility to see threedimensional models overlapped on the archeological ruins. Where possible, in fact, we have developed some virtual wireframe reconstructions, following the filo-logical method of showing the buildings in their original state. These 3D models serve to communicate further levels of information. The representation of the Grand Vestibule, for example, shows the layout of the spaces both open and closed, the lost colonnades, the intended function of each space, the pavements, the ancient pathways for each type of user and the system of underground galleries. Some of the contents of the Web-GIS can be visualized in augmented reality to allow the visitor to see various levels for the passageways overlapped in a way which would be difficult to replicate on a map. This clarifies the relationships between the different users of the Villa: Hadrian, his wife Sabina, the court, the guests and the servants.

\section{REFERENCES.}

\section{References from Journals:}

Com'era, dov'era, 2009. (a cura di) Marconi, P., Pallottino E., Com'era, dov'era. Dopo il terremoto, o la guerra. Ricerche di Storia dell'arte, 99.

De Luca, L., Busayarat, C., Stefani, C., Véron, P., Florenzano, M., 2011. A semantic-based platform for the digital analysis of architectural heritage. Computers \& Graphics, 35(2), pp. 227241.

La "Fabrica", 2007. (a cura di) Degni, P., La "Fabrica" di San Carlino alle Quattro Fontane: gli anni del restauro. Bollettino d'Arte, Volume speciale

La chiesa, 2002. La chiesa di San Giorgio in Velabro a Roma. Storia, documenti, testimonianze del restauro dopo l'attentato del luglio 1993. Bollettino d'Arte, Volume speciale.

Remondino, F., 2011. Rilievo e modellazione 3D di siti e architetture complesse. Disegnarecon, Università di Bologna, 4(8), pp. 90-98.

Salza Prina Ricotti, E., 1982. Villa Adriana nei suoi limiti e nella sua funzionalità. Atti della Pontificia Accademia Romana di Archeologia, Rendiconti, 14, pp. 22-55

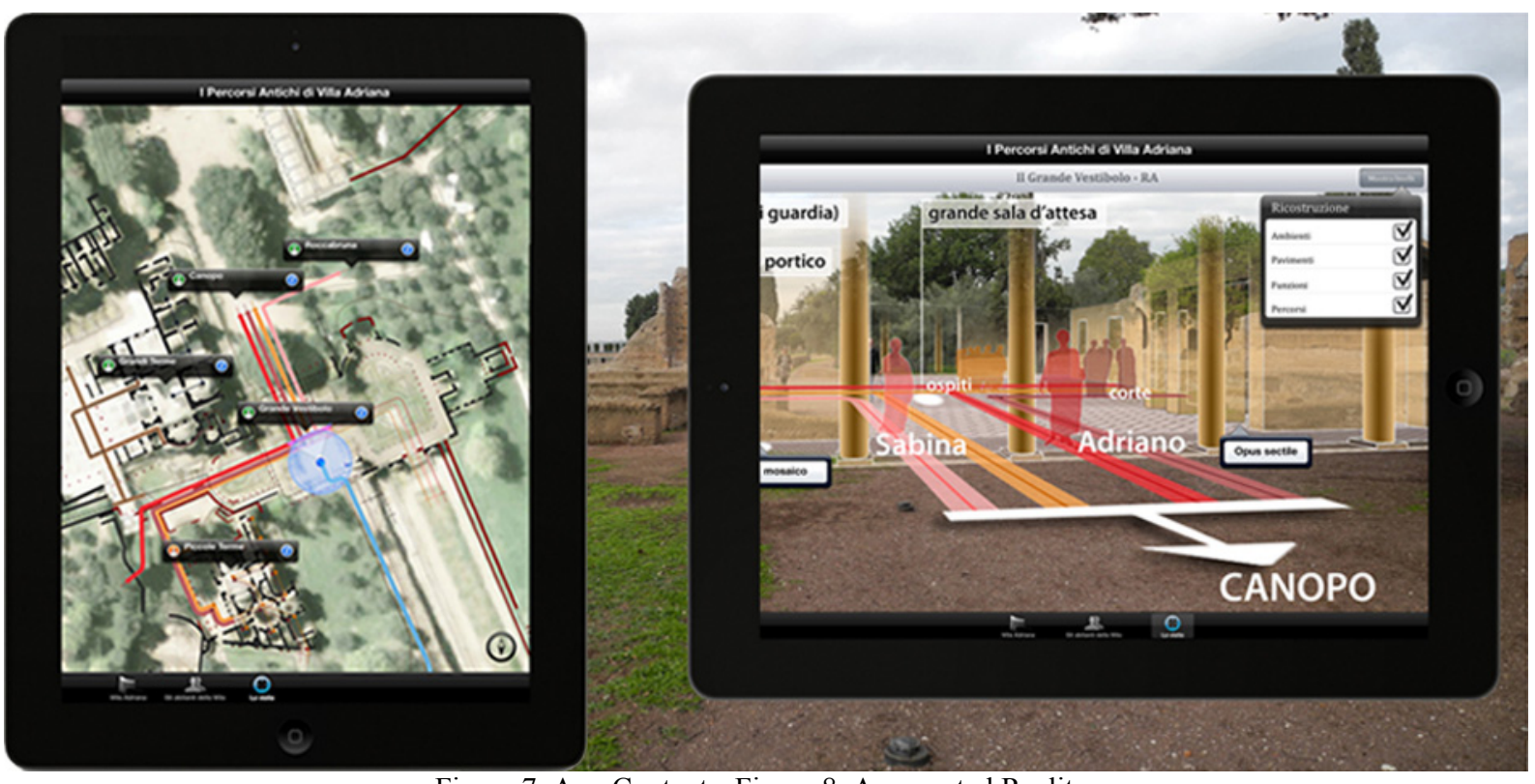

Figure 7. App Contents. Figure 8. Augmented Reality. 
Forte, M., Pescarin, S., 2007. The virtual museum of landscape. Archeologia e Calcolatori, I, pp. 87-99.

Pescarin, S., et al., 2009. Ambienti collaborativi 3D. Il caso di Virtual Rome. Archeologia e Calcolatori, Supplemento, II, pp. 121-130.

Salonia, P.; Negri, A., 2005. ARKIS-NET: un web-GIS per il progetto di conservazione assistito. Archeologia e Calcolatori, XVI, pp. 167-176.

\section{References from Books:}

Chiappetta, F., 2008 . I percorsi antichi di Villa Adriana, Roma.

MacDonald, W. L., Pinto, J., 1997. Villa Adriana. La costruzione e il mito da Adriano a Louis Kahn, Milano.

Piranesi, G. B., 1781. Pianta delle fabbriche esistenti nella Villa Adriana, Roma.

Salza Prina Ricotti, E., 2001. Villa Adriana. Il sogno di un imperatore, Roma.

\section{References from Other Literature:}

Agugiaro G., Remondino F., Girardi G., von Schwerin J., Richards-Rissetto H., De Amicis R., 2011. A Web-based Interactive Tool for Multi-Resolution 3D models of a Maya Archaeological Site. In: ISPRS Archives, Vol. XL-5/W1, pp. 23-30.

Ardissone, P., Bornaz, L., Degattis, G., Domaine, R., 2013. A $3 \mathrm{~d}$ information system for the documentation of archaeologica 1 excavations. In: ISPRS Archives, Vol. XL-5/W2, pp. 55-60.

Brovelli, M., Hogan, P., Minghini, M., Zamboni, G., 2013. The power of Virtual Globes for valorising cultural heritage and enabling sustainable tourism: NASA World Wind applications. In: ISPRS Archives, Vol. XL-4/W2, pp. 115-120.

Canciani, M., Falcolini, C., Saccone, M., Spadafora, G., 2013. From point cloud to Architectural models: algorithms for shape reconstruction. In: ISPRS Archives, Vol. XL-5/W1, pp. 27-34.

Chiappetta, F., 2003. Villa Adriana: la restituzione dei percorsi antichi (117-138 d.C.), Tesi di laurea in Architettura - Restauro, relatori F. Donato - E. Pallottino, correlatori C. Bedoni - E. Salza Prina Ricotti, Università Roma Tre - Facoltà di Architettura.

De Amorim, A. L., Fangi, G., Malinverni, E. S., 2013. Documenting architectural heritage in Bahia, Brazil, using spherical photogrammetry. In: ISPRS Archives, Vol. XL-5/W2, pp. 219-224.

Drap, P., Seinturier, J., Chambelland, J.C., Pruno, E., 2009. Going To Shawbak (Jordan) And Getting The Data Back: toward a 3D GIS dedicated to medieval archaeology. In: ISPRS Archives, Vol. XXXVIII-5/W1.

Koehl, M., Schneider, A., Fritsch, E., Fritsch, F., Rachedi, A., Guillemin, S., 2013: Documentation of historical building via virtual tour: the complex building of baths in Strasbourg. In: ISPRS Archives, Vol. XL-5/W2, pp. 385-390.
Mari, Z., Reggiani, A. M., Righi, R., 2000. Grande Vestibolo presso le Cento Camerelle. In: Indagini e restauri, Archeologia e Giubileo. Gli interventi a Roma e nel Lazio nel Piano per il Grande Giubileo del 2000, Napoli, pp. 478-483.

Mari, Z., Reggiani, A. M., Righi, R., 2002. Il Grande Vestibolo di Villa Adriana. In: Villa Adriana. Paesaggio antico $e$ ambiente moderno: elementi di novità e ricerche in corso, Milano, pp. 16-29.

Michelini, M., Scortecci, A., 2013. I percorsi antichi di villa Adriana: nuovi strumenti di valorizzazione, Tesi di laurea in Architettura - Restauro, relatori M.Canciani - E.Pallottino, correlatori Z.Mari - M.Saccone, Università Roma Tre Dipartimento di Architettura.

Panella, C., Brienza, E., Carlani, R., 2008. A 3D Web-Gis for the Coliseum Valley and the Palatine Hill. In: Computer Application and Quantitative Methods in Archaeology, International Conference, Berlin.

Panella, C., Fano, M., Brienza, E., Carlani, R., 2008. A 3D Web-GIS for the Valley of the Colosseum and the Palatine Hill. In: International Conference on Computer Applications and Quantitative Methods in Archaeology, Berlin.

Pietroni, E., 2012a (September). An augmented experiences in cultural heritage through mobile devices: "Matera tales of a city" project. In: Virtual Systems and Multimedia (VSMM), 18th International Conference on , pp. 117-124.

Pietroni, E., Ray, C., Rufa, C., Pletinckx, D., Van Kampen, I., 2012b, (September). Natural interaction in VR environments for Cultural Heritage and its impact inside museums: The Etruscanning project. In: Virtual Systems and Multimedia (VSMM), 18th International Conference on , pp. 339-346.

Saygi, G., Agugiaro, G., Hamamcığlu-Turan, M., Remondino, F., 2013. Evaluation of GIS and bim roles for the information management of historical buildings. In: ISPRS Ann. Photogramm. Remote Sens. Spatial. Inf. Sci., II-5/W1, pp. 283288.

\section{References from websites:}

NoReal.it, 2011a. La Villa di Traiano

http://www.noreal.it/site2011/index.php?option=com content\& view=article \&id=316:la-valle-degli-imperatori-la-villa-ditraiano\&catid $=15 \&$ Itemid $=177 \&$ lang $=$ it

NoReal.it, 2011b. AR-Etruschi

http://www.vhlab.itabc.cnr.it/archeovirtual/2011/noreal.htm

Meshlab.net, http://meshlab.sourceforge.net/

Photosynt.net, http://photosynth.net/ 